Article

\title{
Evaluation of Nanoporous Carbon Synthesized from Direct Carbonization of a Metal-Organic Complex as a Highly Effective Dye Adsorbent and Supercapacitor
}

\author{
Xiaoze Shi ${ }^{1}$, Shuai Zhang ${ }^{1}$, Xuecheng Chen ${ }^{1,2, *(\mathbb{D})}$ and Ewa Mijowska ${ }^{1, *(D)}$ \\ 1 Nanomaterials Physicochemistry Department, Faculty of Chemical Technology and Engineering, \\ West Pomeranian University of Technology, Szczecin, Piastów Ave. 42, 71-065 Szczecin, Poland; \\ xiaoze.shi@zut.edu.pl (X.S.); shuai.zhang@zut.edu.pl (S.Z.) \\ 2 State Key Laboratory of Polymer Physics and Chemistry, Changchun Institute of Applied Chemistry, \\ Chinese Academy of Science, Changchun 130021, China \\ * Correspondence: xchen@zut.edu.pl (X.C.); emijowska@zut.edu.pl (E.M.); \\ Tel.: +48-91-449-6030 (X.C.); +48-91-449-4742 (E.M.)
}

Received: 13 March 2019; Accepted: 10 April 2019; Published: 11 April 2019

\begin{abstract}
The synthesis of interconnected nanoporous carbon (NPC) material from direct annealing of ultra-small Al-based metal-organic complex (Al-MOC) has been demonstrated. NPC presents a large accessible area of $1054 \mathrm{~m}^{2} / \mathrm{g}$, through the Methylene Blue (MB) adsorption method, which is comparable to the high specific surface area (SSA) of $1593 \mathrm{~m}^{2} / \mathrm{g}$, through an $\mathrm{N}_{2}$ adsorption/desorption analysis. The adsorption properties and mechanisms were tested by various dye concentrations, $\mathrm{pH}$, and temperature conditions. The high $\mathrm{MB}$ accessible area and the good electrical conductivity of the interconnected NPC, led to a large specific capacitance of $205 \mathrm{~F} / \mathrm{g}$, with a potential window from 0 to $1.2 \mathrm{~V}$, in a symmetric supercapacitor, and a large energy density of $10.25 \mathrm{Wh} / \mathrm{kg}$, in an aqueous electrolyte, suggesting a large potential in supercapacitors.
\end{abstract}

Keywords: nanoporous carbon; adsorption properties; dye; adsorption models; supercapacitor

\section{Introduction}

Nanoporous carbon (NPC) materials with large specific surface area (SSA), have been applied in different fields, especially, as electrode materials and dye adsorbents [1-3]. Dyes are applied in many different industrial fields, such as paper, textile, rubber, food, leather, cosmetics, plastic, and others. However, used dyes also become harmful, due to the fact that they can not only reduce light penetration and photosynthesis in water, but can also contain toxic and carcinogenic chemicals that might be a threat to human health [4]. Unfortunately, most of the wasted dyes are quite stable in the real environment [5]. Therefore, removing dyes from industrial waste water, through efficient technologies, is quite urgent. Adsorption is considered as an economical and efficient method. The adsorption method has the advantages of a simple design, easy operation, and possible regeneration. Methylene Blue (MB) has become a model cationic dye for dye adsorption investigations [6,7]. Various adsorbents, such as biomass materials [8-12], carbon nanotubes [13-16], graphene-based materials [17-20], and magnetic materials [21,22], have been investigated in the field of dye removal. Additionally, researchers always use the MB adsorption method to test the surface area of carbon samples, which can indicate the accessible surface of electrodes [23,24].

Carbon materials are also popular as electrode materials, due to their good electrical conductivity, high power density, and good cycling stability [25-29]. Many efforts have been made in these aspects to fabricate NPC materials with excellent properties, including a large SSA and high porosity. As it has been reported, NPC can be synthesized by various methods, such as chemical vapor decomposition 
(CVD), chemical activation, and template methods [30-32]. Among these, the template method has drawn a lot of interest. Easily acquiring zeolites and mesoporous silica have been effectively used as templates, for the formation of NPC with different sizes and structures. Metal-organic frameworks (MOF) have become a new choice of precursors for NPC materials [33-35]. There are two types of MOF-derived NPC materials, depending on the production process. One induces a secondary carbon precursor and the other is a direct carbonization of the organic components of MOF. MOF-derived NPC materials possess a high SSA and a tunable pore size. The tunable pores can provide an appropriate size for the electrolyte ions and dye molecules diffusion, thus, increasing the accessible area and providing more physical active sites for the adsorption process. However, the specific capacitance of the MOF-derived NPC reported so far, is still not satisfactory. Due to the large size of the MOF template [36,37], it is difficult for electrolyte and ions to transport into the inner or the center of the micrometer-sized NPC, leaving many inaccessible active sites. Thus, the resultant specific capacitance is limited, especially under a high charging rate. In this respect, decreasing the MOF size is conducive to improving the electrochemical performance. Additionally, a proper pore size distribution (PSD) can also help to improve the capacitance [38].

Herein, we have prepared an interconnected NPC material from a direct carbonization of the ultra-small Al-MOC. NPC presents a high Brunauer-Emmett-Teller (BET) area, showing an excellent adsorption capacity for MB. NPC can adsorb MB with a maximum value of $415 \mathrm{mg} / \mathrm{g}$, via a physical adsorption process, which suggests a large molecular accessible area of $1054 \mathrm{~m}^{2} / \mathrm{g}$, very close to the SSA from the $\mathrm{N}_{2}$ adsorption/desorption analysis $\left(1593 \mathrm{~m}^{2} / \mathrm{g}\right)$. The large accessible surface area, together with the suitable pore distribution (micropores and mesopores) and high conductivity of the NPC, makes it a good candidate for an electrode material. Hence, a two-electrode supercapacitor has been designed with the NPC material, exhibiting a large specific capacitance of $226 \mathrm{~F} / \mathrm{g}$ and an energy density of $10.25 \mathrm{Wh} / \mathrm{kg}$, in an aqueous electrolyte.

\section{Materials and Methods}

\subsection{Synthesis of NPC}

NPC was fabricated from Al-MOC, according to our previous report [2]. In brief, $2 \mathrm{~g}$ of the $\mathrm{Al}-\mathrm{MOC}$ was heated at $950{ }^{\circ} \mathrm{C}$, for $3 \mathrm{~h}$, in $\mathrm{Ar}$ atmosphere and then treated with $10 \mathrm{~mL} 17 \% \mathrm{HCl}$, to remove the metal components. The final product was dried at $105^{\circ} \mathrm{C}$ and named as NPC. All the chemicals were purchased from MERCK (Darmstadt, Germany).

\subsection{Characterization}

Transmission electron microscopy (TEM), High-resolution transmission electron microscopy (HRTEM) (Tecnai F30, FEI, Eindhoven, The Netherlands), Scanning Electron Microscopy (SEM, Hitachi SU8020, Tokyo, Japan), X-ray diffraction using Copper K- $\alpha$ with an X-ray wavelength of $1.5406 \AA$ (XRD, X'Pert PRO Philips diffractometer, Almelo, Holland), and Raman scattering (Renishawmicro, Renishaw, London, UK; $\lambda=785 \mathrm{~nm}$ ) were performed, to characterize the structural properties. Thermogravimetric analysis (TGA, DTA-Q600 SDT TA, New Castel, DE, USA) was conducted to determine the composition. The $\mathrm{N}_{2}$ adsorption/desorption analysis (Micromeritics ASAP 2010M, Boynton Beach, FL, USA) were used to calculate the SSA and the PSD. UV-vis spectrophotometer (Thermo Scientific, Waltham, MA, USA) was applied to calculate the concentration of MB.

\subsection{Adsorption Equilibrium Isotherm}

NPC (W: $0.02 \mathrm{~g}$ ) was dissolved in a constant volume (V: $0.02 \mathrm{~L}$ ) of MB aqueous solutions, with different initial concentrations $\left(C_{0}: 100\right.$ to $\left.900 \mathrm{mg} / \mathrm{L}\right)$, at $25^{\circ} \mathrm{C}$, for $24 \mathrm{~h}$. The $\mathrm{MB}$ concentrations in the supernatant were measured as $C_{\mathrm{e}}(\mathrm{mg} / \mathrm{L})$ and the adsorbed dye amounts by NPC $\left(q_{\mathrm{e}}, \mathrm{mg} / \mathrm{g}\right)$ were calculated as follows:

$$
q_{\mathrm{e}}=\frac{\left(C_{0}-C_{\mathrm{e}}\right) V}{W}
$$




\subsection{Adsorption Kinetics}

The adsorption kinetic measurements were carried out by continuously stirring the NPC and MB solutions $\left(C_{0}: 200,400\right.$, or $\left.600 \mathrm{mg} / \mathrm{L}\right)$. The concentrations of $\mathrm{MB}\left(C_{\mathrm{t}}: \mathrm{mg} / \mathrm{L}\right)$ in the supernatant were checked at preset time intervals $(t: \mathrm{min})$, to calculate the adsorbed MB amount at time $\left(q_{\mathrm{t}}, \mathrm{mg} / \mathrm{g}\right)$ :

$$
q_{\mathrm{t}}=\frac{\left(C_{0}-C_{\mathrm{t}}\right) V}{W}
$$

\subsection{Adsorption Thermodynamics}

To observe the influence of different temperatures on the adsorption capacity, NPC and MB solutions (500 or $700 \mathrm{mg} / \mathrm{L})$ were placed under different temperatures $\left(25,35,45\right.$, or $\left.55^{\circ} \mathrm{C}\right)$ and stirred for $24 \mathrm{~h}$. The concentrations of MB and the amounts of MB adsorbed onto the NPC, at equilibrium, were measured, similar to that of adsorption equilibrium experiments.

\subsection{Effect of $p H$ Values}

Five different $\mathrm{pH}$ values $(3.62,5.14,7.21,8.76$, and 10.20) were investigated by adjusting the $\mathrm{pH}$ of $\mathrm{MB}(400 \mathrm{mg} / \mathrm{L})$ solution, with $\mathrm{NaOH}$ or $\mathrm{HCl}(0.1 \mathrm{M})$.

\subsection{Electrochemical Evaluation}

NPC (80 wt.\%) was mixed with carbon nanotubes (Sigma, Kawasaki, Kanagawa Prefecture, Japan; $10 \mathrm{wt} . \%$ ) and polyvinylidenedifluoride (Solvay, Brussels, Belgium; $10 \mathrm{wt} . \%$ ), and the electrode $(d: 1 \mathrm{~cm})$ was prepared by pressing the mixture at $10 \mathrm{MPa}$. A two-electrode system was used with active materials mass of $2 \mathrm{mg}$. The cyclic voltammetry $(\mathrm{CV})$, galvanostatic charging/discharging (GCD), and electrochemical impedance spectroscopy (EIS) tests were performed on the EC-LAB VMP3 workstation (BioLogic Science Instruments, Seyssinet-Pariset, France), with $1 \mathrm{M} \mathrm{Li}_{2} \mathrm{SO}_{4}$ aqueous solution.

\section{Results and Discussion}

The morphology of NPC material is presented by SEM and TEM. Figure 1 shows the TEM images of the Al-MOC, before (Figure 1a) and after carbonization (Figure 1b). Al-MOC, which had an XRD pattern (Figure S1) comparable to the MIL-53 (Al) from the report [39], exhibited separated nanocubes with ultra-small size around $100 \mathrm{~nm}$, while NPC turned into an interconnected three-dimensional bulk structure, after sintering under high temperatures (Figure 1b). SEM image of NPC also indicated a large size, after annealing (Figure S2). XRD pattern of the obtained NPC is shown in Figure 1c. The NPC powder presents the graphitic carbon (002) and (101) diffractions. The presence of (002) diffraction at $2 \theta=23^{\circ}$ shifted to the left, compared to the perfect graphite diffraction at $2 \theta=26^{\circ}$, suggesting that the NPC sample had a low crystallinity [40]. TGA data (Figure 1d) showed a negligible weight of the remaining NPC, after heating to $900{ }^{\circ} \mathrm{C}$, suggesting a successful removal of alumina. 

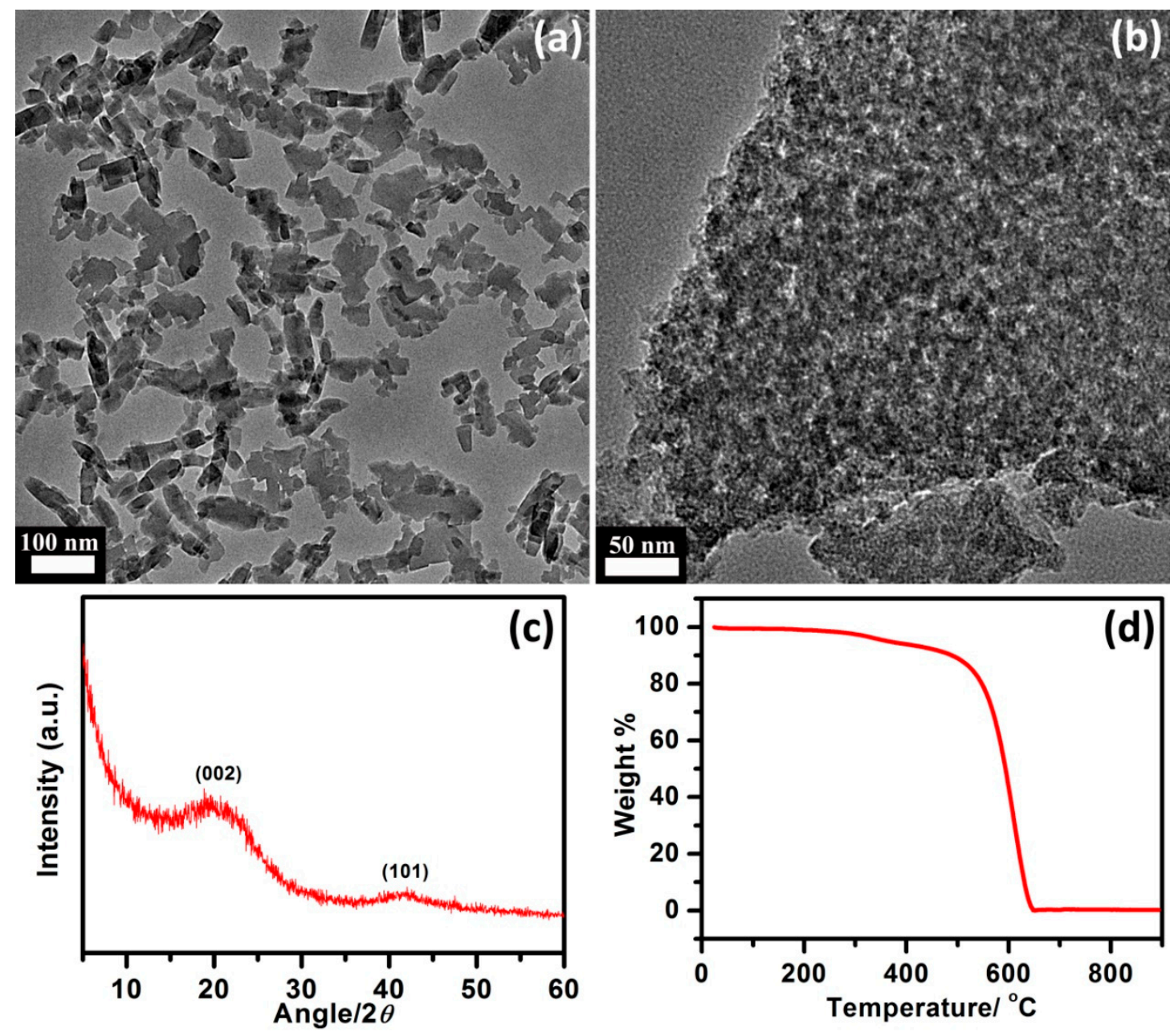

Figure 1. TEM images of Al-based metal-organic complex (Al-MOC) (a) and nanoporous carbon (NPC) (b); XRD pattern (c) and TGA curve (d) of NPC.

Although NPC showed an interconnected structure after high-temperature annealing, the HRTEM (Figure S3) images still exhibited an amorphous structure. Notably, irregular mesopores can be found from the agglomerate (Figure S3a-c). In order to achieve the detailed information, the $\mathrm{N}_{2}$ adsorption-desorption isotherm within the relative pressure of $0-1$ was measured. The isotherm in Figure 2a exhibits a typical type IV profile, suggesting the existence of micro-, meso- and macropores. It was calculated that the SSA of NPC was $1593 \mathrm{~m}^{2} / \mathrm{g}$ and the total pore volume was $2.49 \mathrm{~cm}^{3} / \mathrm{g}$ (Figure 2b), due to the new pores that appeared among the agglomerated complex in bulk NPC. Raman spectrum (Figure 2c) of the NPC sample showed two peaks at 1324 (D band) and 1580 1/cm ( $\mathrm{G}$ band). The $\mathrm{D}$ and $\mathrm{G}$ bands were ascribed to the disordered carbons and ideal graphitic carbon, respectively [41]. The intensity ratio $\mathrm{I}_{\mathrm{D}} / \mathrm{I}_{\mathrm{G}}$ for the NPC was 1.36 , suggesting the disordered nature for NPC. 

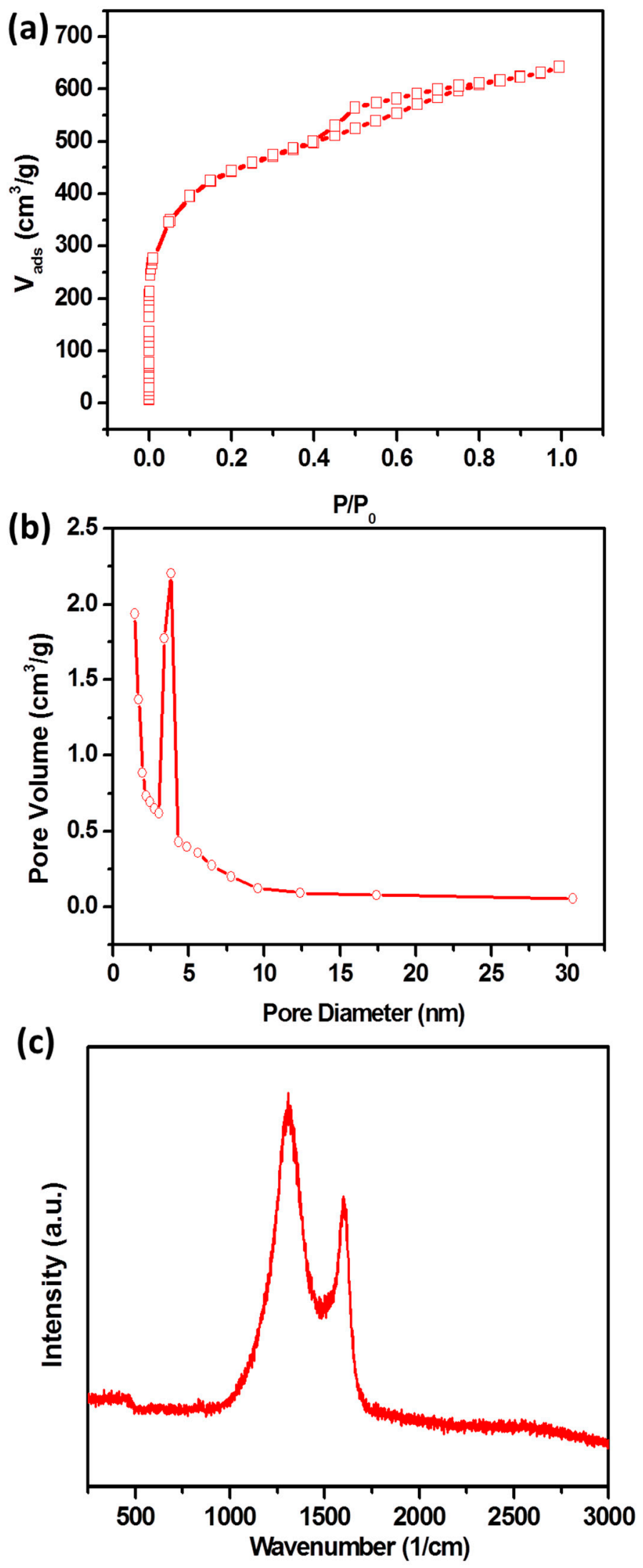

Figure 2. Nitrogen adsorption/desorption isotherms (a), pore size distributions (b), and Raman spectrum (c) of NPC. 
Encouraged by the large SSA and the well-distributed porous structure, the adsorption properties of NPC were tested. First, the adsorption process was studied with different dye concentrations. A fast color fading could be observed with the low-concentration groups, and then the adsorption equilibrium, proceed slowly with the high-concentration groups. The fast color fading indicated a fast adsorption rate, which was contributed by the large SSA, as well as the large pore volume. Figure 3 shows that there was a significant increase of the adsorption capacities, with the first four concentrations, which grew slowly, with the latter five concentrations. This could be proved by the well-fitted Langmuir model [42], indicating a monolayer adsorption behavior, which meant that no further dye adsorption could happen at the occupied site of the NPC. The fitted Langmuir isotherm could be defined in the following form:

$$
\frac{C_{\mathrm{e}}}{q_{\mathrm{e}}}=\frac{C_{\mathrm{e}}}{q_{\max }}+\frac{1}{K_{\mathrm{L}} q_{\max }}
$$

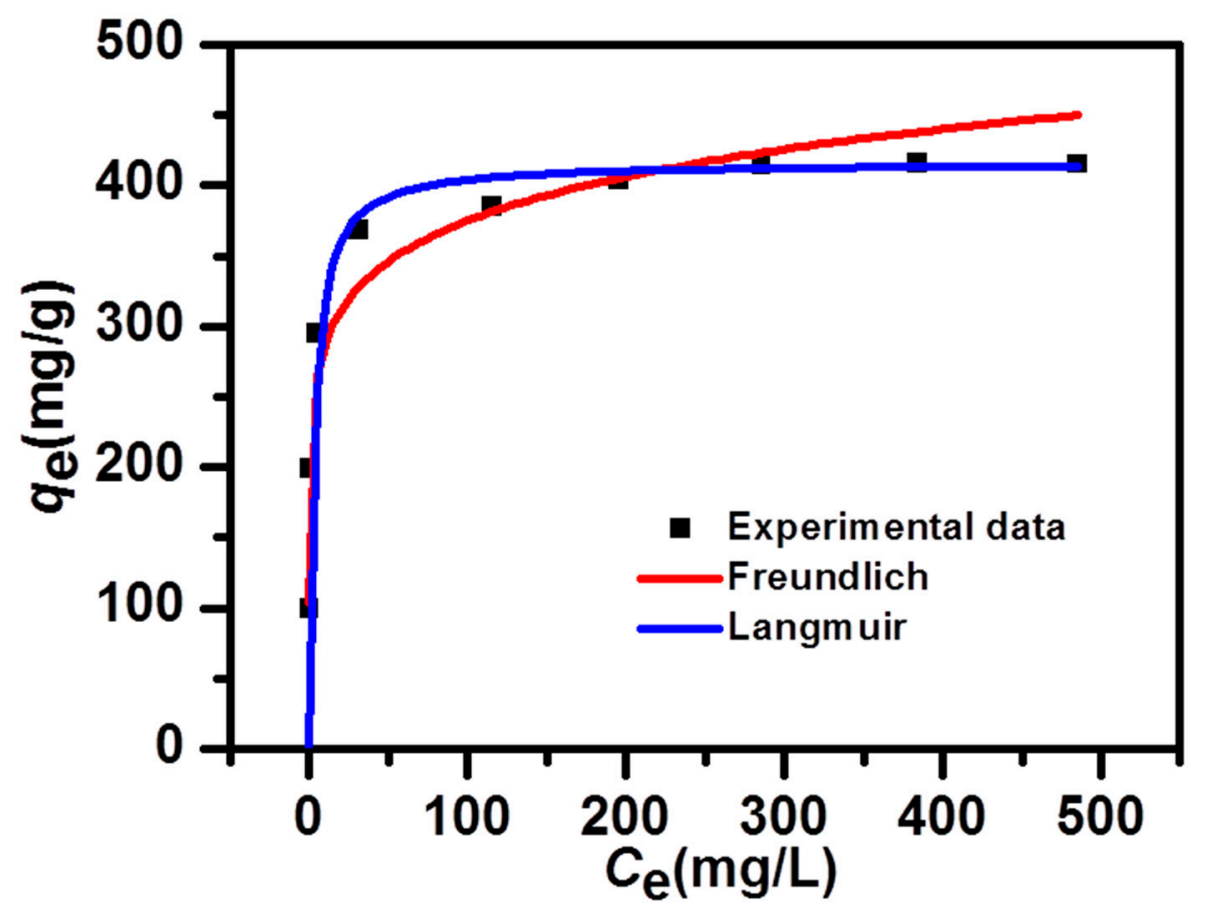

Figure 3. Non-linear fits of the Langmuir and Freundlich isotherm models, to the Methylene Blue (MB) adsorption.

From Figure $4 \mathrm{a}, q_{\max }(\mathrm{mg} / \mathrm{g})$ is the maximum amount of MB adsorbed onto the NPC and the constant $\left(K_{\mathrm{L}}: \mathrm{L} / \mathrm{mg}\right)$ had a relationship to the rate of adsorption. Additionally, the $R_{\mathrm{L}}$ parameter which indicated the adsorption process to be favorable $\left(0<R_{\mathrm{L}}<1\right)$ or unfavorable with the isotherm $\left(R_{\mathrm{L}}>1\right)$, was calculated as follows [43]:

$$
R_{\mathrm{L}}=\frac{1}{1+K_{\mathrm{L}} \mathrm{C}_{0}}
$$

The Freundlich isotherm model which demonstrated a heterogeneous adsorption process [44], could be written in the following form:

$$
\ln q_{\mathrm{e}}=\ln K_{\mathrm{F}}+\frac{1}{n} \ln C_{\mathrm{e}}
$$

where the constants $\left(K_{\mathrm{F}}\right.$ and $\left.n\right)$ are related to the intercept and the slope of Figure $4 \mathrm{~b}$. The parameters for adsorption isotherms calculated from the above Equations (3)-(5) are shown in Table 1. The correlation 
coefficient $\left(R^{2}\right)$ values indicated that the dye adsorption process was well-matched to both models, but was better matched to the Langmuir isotherm model. It revealed that the dye adsorption started on both the homogeneous and heterogeneous active sites of NPC. The heterogeneous sites were from the possible functional groups contained on the NPC surface. There were negligible differences between the maximum adsorption capacity $\left(q_{\max }\right)$ fitted by the Langmuir model $(417 \mathrm{mg} / \mathrm{g})$, and the experimental value $(415 \mathrm{mg} / \mathrm{g})$, which also proved to be a better match to the Langmuir isotherm. According to Table 1 , the $R_{\mathrm{L}}$ value was near zero (0.0035), illustrating that the adsorption process was favorable and irreversible. Value $n(8.656)$ in the range of 1-10, also illustrated that this adsorption was favorable $[45,46]$.
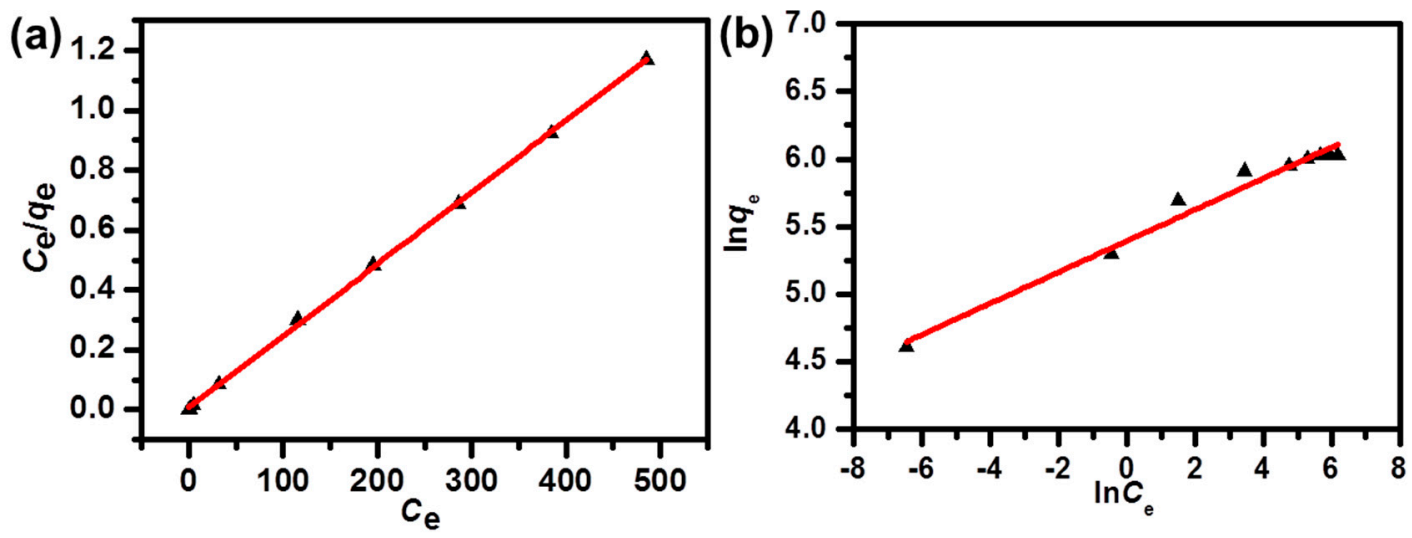

Figure 4. Linear fits of the Langmuir (a) and Freundlich (b) isotherms for the MB adsorption on the NPC samples.

Table 1. Parameters of the Langmuir and Freundlich isotherms for the adsorption of $\mathrm{MB}$ on the NPC samples.

\begin{tabular}{ccccccc}
\hline & $q_{\max }(\mathbf{m g} / \mathbf{g})$ & $\boldsymbol{K}_{\mathbf{L}}(\mathbf{L} / \mathbf{m g})$ & $\boldsymbol{R}_{\mathbf{L}}$ & $\boldsymbol{K}_{\mathrm{F}}$ & $n$ & $\boldsymbol{R}_{\mathbf{2}}$ \\
\hline Langmuir & 417 & 0.317 & 0.0035 & - & - & 0.999667 \\
Freundlich & - & - & - & 220.256 & 8.656 & 0.974407 \\
\hline
\end{tabular}

To study the effect of time, adsorption kinetics was measured by choosing different time intervals. Adsorption kinetics could also help to quantify the adsorption rate and illustrate the mechanism of adsorption. The adsorption kinetics of the MB-NPC was obtained by three different MB concentrations $(200,400$, and $600 \mathrm{mg} / \mathrm{L})$. The MB adsorption was rapid in the first $5 \mathrm{~min}$ (Figure 5), and then the adsorption rate gradually slowed down, with the proceeding time. At last, the adsorption achieved equilibrium, within $2 \mathrm{~h}$. Four kinetics models were applied to figure out the kinetic mechanism of the dye adsorption. First, the adsorption kinetics was examined by the pseudo-first-order model. The equation is described as follows [47]:

$$
\ln \left(q_{\mathrm{e}}-q_{\mathrm{t}}\right)=\ln q_{\mathrm{e}}-k_{1} t
$$

Based on the equation, the plots of $\ln \left(q_{\mathrm{e}}-q_{\mathrm{t}}\right)$ versus $\mathrm{t}$ (Figure 6a) can be used to calculate $k_{1}$ and $q_{\mathrm{e}}$. Second, the pseudo-second-order equation can be expressed as follows [48]:

$$
\frac{t}{q_{\mathrm{t}}}=\frac{1}{k_{2} q_{\mathrm{e}}^{2}}+\frac{1}{q_{\mathrm{e}}} t
$$

Based on this equation, $q_{\mathrm{e}}$ and $k_{2}$ calculated from the plots of $\mathrm{t} / q_{\mathrm{t}}$ versus $\mathrm{t}$ (Figure $6 \mathrm{~b}$ ) are shown in Table 2 . The corresponding $R^{2}$ values in the pseudo-first-order kinetic model $(<0,920)$ are relatively smaller than in the pseudo-second-order kinetic model (0.999). Moreover, the $q_{\mathrm{e}}$ values of the pseudo-second-order model from the fitted linear plots, are better agreed with the experimental data than those of the pseudo-first-order model, indicating that, in this work, it was more appropriate using the pseudo-second-order kinetic model, to describe the adsorption kinetics. 


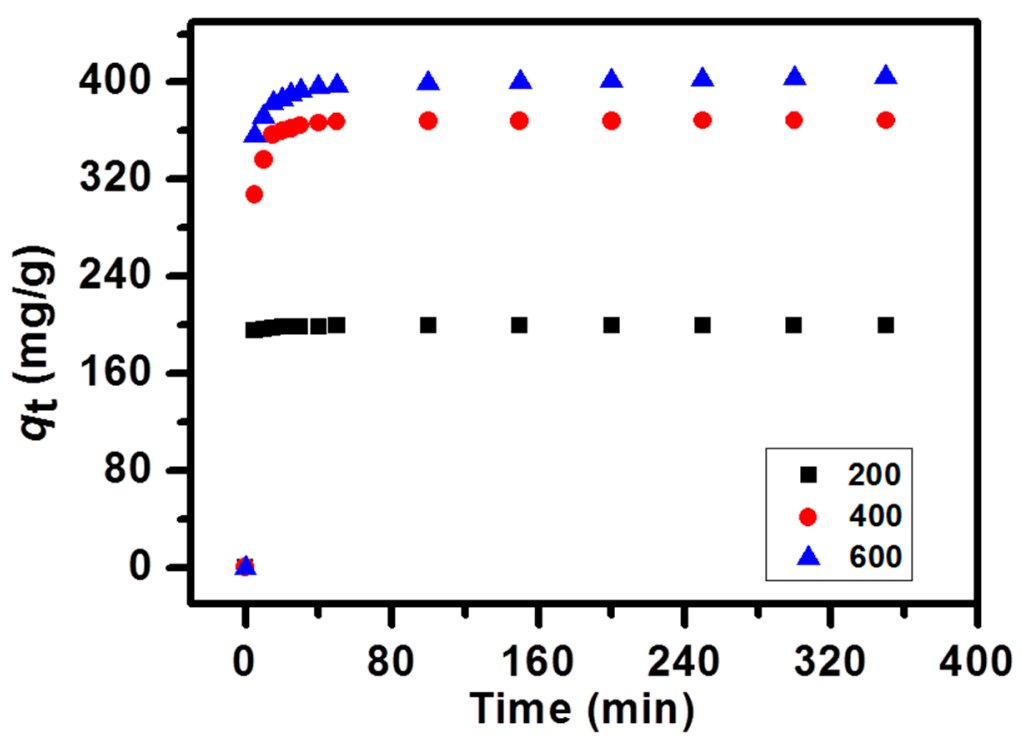

Figure 5. Effect of contact time on the adsorption capacity of MB on NPC samples.
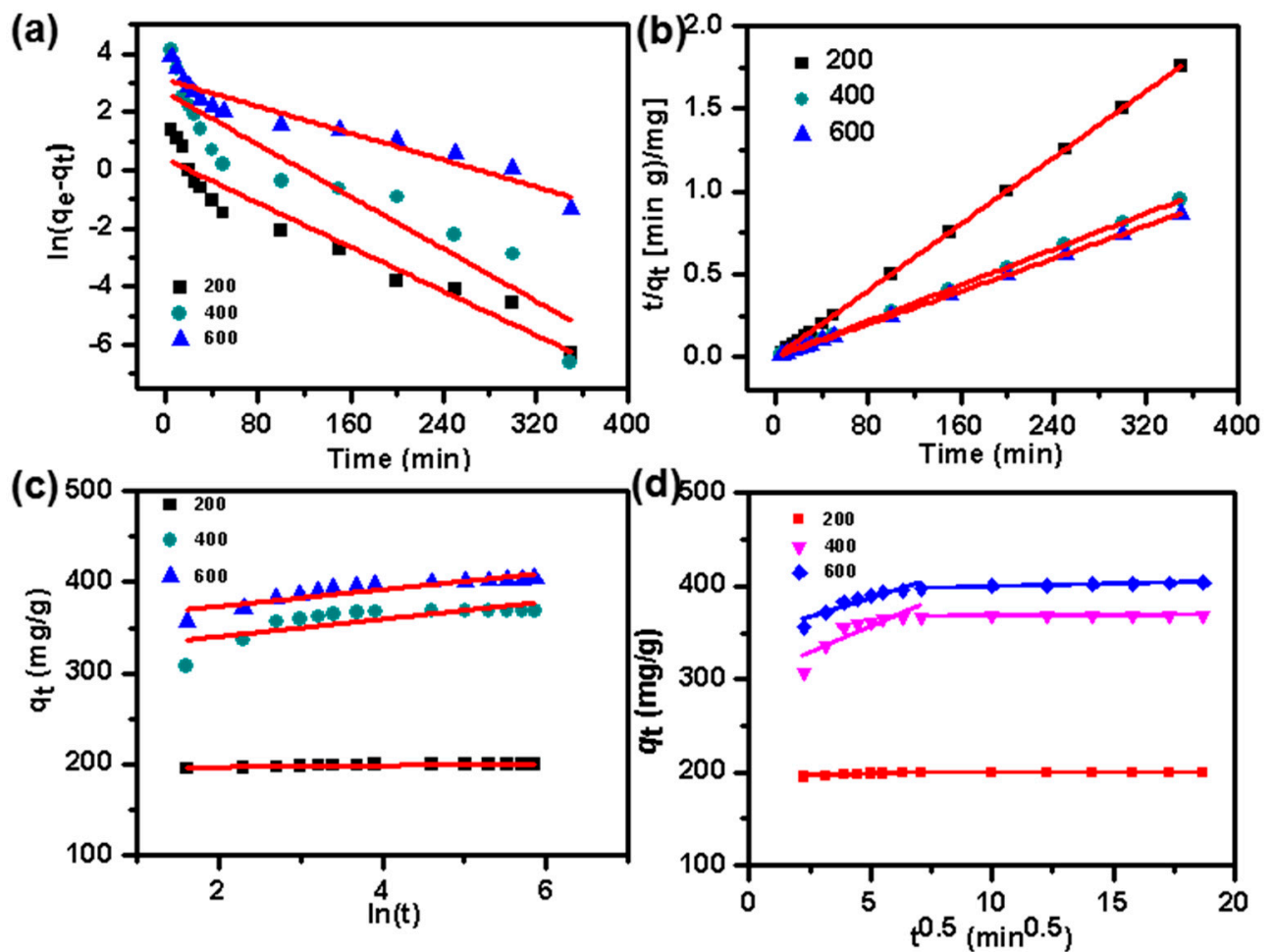

Figure 6. Linear fits of pseudo-first-order kinetics (a), pseudo-second-order kinetics (b), Elovich kinetic (c), and intraparticle diffusion (d) models for the adsorption of MB on the NPC samples.

The Elovich model, which can be used to identify chemical adsorption, is described as follows [49]:

$$
q_{t}=\frac{1}{\beta} \ln (\alpha \beta)+\frac{1}{\beta} \ln (t)
$$

where $\alpha$ and $\beta$ values correspond to the initial adsorption and desorption rate, respectively. As shown in Table 2, the large $\alpha$ shows the viability of the MB-NPC adsorption, while the low value of $\beta$ confirms that the MB-NPC adsorption is essentially irreversible [50,51]. This model, with a low value of $R^{2}$, 
has a poor linearity (Figure 6c), considering that the mechanism of adsorption did not occur via chemical adsorption.

Dye adsorption might involve the following three sequential steps-(1) external adsorption on the sorbent surface, (2) dye diffusion to the sorbent pore or intraparticle diffusion, and (3) chemical adsorption $[7,52,53]$. These steps can be investigated by the intraparticle diffusion model described as follows [54]:

$$
q_{t=k_{\mathrm{i}} t^{0.5}+\mathrm{C}}
$$

Based on this equation, the plot of $q_{\mathrm{t}}$ versus $\mathrm{t}^{0.5}$ could be used to calculate the intraparticle diffusion rate constant $\left(k_{\mathrm{i}}: \mathrm{mg} / \mathrm{g} / \mathrm{min}^{0.5}\right)$ and $C(\mathrm{mg} / \mathrm{g})$ (Figure $6 \mathrm{~d}$ ). The corresponding parameters are listed in Table 2. As shown in Figure $6 \mathrm{~d}$, there are two linear plots, by fitting $q_{\mathrm{t}}$ versus $\mathrm{t}^{0.5}$, suggesting that intraparticle diffusion was involved but was not the predominant mechanism in the adsorption process. Thus, there might be other factors that could influence the adsorption kinetics [53,55]. The concentrations showed two defined stages (Figure $6 \mathrm{~d}$ ). For all concentrations, the first stage had a higher slope, indicating the external and boundary diffusion of the dye adsorption on the NPC surface. The second linear stage showed a drop in the slope, which could be assigned to the intraparticle diffusion. The $C$ values could be used to evaluate the diffusion resistance, suggesting the thickness of the boundary layer. The $C$ values showed an increasing trend towards the dye concentrations (Table 2), which meant that the boundary layer diffusion had a larger effect on the high initial dye concentration.

Table 2. Parameters of the kinetic models for the adsorption of MB on the NPC samples.

\begin{tabular}{|c|c|c|c|}
\hline & \multicolumn{3}{|c|}{$C_{0}(\mathrm{mg} / \mathrm{L})$} \\
\hline & 200 & 400 & 600 \\
\hline$q_{\mathrm{e}, \exp }(\mathrm{mg} / \mathrm{g})$ & 199.36 & 368.63 & 404.42 \\
\hline \multicolumn{4}{|c|}{ Pseudo-1st-order } \\
\hline$q_{\mathrm{e}}(\mathrm{mg} / \mathrm{g})$ & 1.46 & 14.44 & 22.46 \\
\hline$k_{1}(1 / \mathrm{min})$ & 0.01887 & 0.02236 & 0.01148 \\
\hline$R_{2}$ & 0.91945 & 0.87247 & 0.90755 \\
\hline \multicolumn{4}{|c|}{ Pseudo-2nd-order } \\
\hline$q_{\mathrm{e}}(\mathrm{mg} / \mathrm{g})$ & 199.6 & 369 & 404.9 \\
\hline$k_{2}(\mathrm{~g} / \mathrm{mg} / \mathrm{min})$ & 0.000005 & 0.004877 & 0.002537 \\
\hline$R_{2}$ & 0.999999 & 0.999996 & 0.999993 \\
\hline \multicolumn{4}{|c|}{ Elovich } \\
\hline$\alpha(\mathrm{mg} / \mathrm{g} / \mathrm{min})$ & - & $3.1 \times 10^{15}$ & $5.3 \times 10^{17}$ \\
\hline$\beta(\mathrm{g} / \mathrm{mg})$ & 1.261 & 0.104 & 0.109 \\
\hline$R_{2}$ & 0.69778 & 0.53520 & 0.80215 \\
\hline \multicolumn{4}{|c|}{ Intraparticle diffusion } \\
\hline$K_{\mathrm{d}}$ & 0.01903 & 0.10303 & 0.58545 \\
\hline $\mathrm{C}$ & 199.0359 & 366.7999 & 393.3279 \\
\hline$R_{2}$ & 0.859991 & 0.949224 & 0.983385 \\
\hline
\end{tabular}

Temperature is another important factor for the dye adsorption. The temperature effect was investigated at $25,35,45$, and $55^{\circ} \mathrm{C}$, with two $\mathrm{MB}$ initial concentrations ( 500 or $700 \mathrm{mg} / \mathrm{L}$ ). The thermodynamic equations were as follows:

$$
\begin{gathered}
K_{\mathrm{D}}=\frac{q_{\mathrm{e}}}{C_{\mathrm{e}}} \\
\Delta \mathrm{G}=-\mathrm{R} \ln K_{\mathrm{D}} \\
\ln K_{\mathrm{D}}=\frac{\Delta \mathrm{S}}{\mathrm{R}}-\frac{\Delta \mathrm{H}}{\mathrm{RT}}
\end{gathered}
$$

where $K_{\mathrm{D}}$ was the adsorption constant, $\mathrm{T}(\mathrm{K})$ is the temperature, $R(8.314 \mathrm{~J} / \mathrm{mol} / \mathrm{K})$ is the gas constant, and $\Delta \mathrm{G}^{\theta}$ is the change of the Gibbs free energy $(\mathrm{kJ} / \mathrm{mol})$, the change of enthalpy $\left(\left(\Delta \mathrm{H}^{\theta}, \mathrm{kJ} / \mathrm{mol}\right)\right.$, and the change of entropy $\left(\Delta \mathrm{S}^{\theta}, \mathrm{J} / \mathrm{mol} / \mathrm{K}\right)$, which could be calculated from the slope and the intercept of $\ln K_{\mathrm{D}}$ 
against the 1/T plot (Figure 7). Table 3 shows the thermodynamic parameters obtained from MB-NPC adsorption. The $\Delta \mathrm{G}^{\theta}$ was negative, proving that the adsorption of MB on the NPC was spontaneous in the temperature set, and the positive values of $\Delta \mathrm{H}^{\theta}$ confirmed that the adsorption process was endothermic. Furthermore, $\Delta \mathrm{G}^{\theta}$ changed to more negative values with increasing temperature, indicating that the MB-NPC adsorption was more favorable at a higher temperature, which could also be revealed by the increased experimental adsorption, under a higher temperature. In addition, the values of $\Delta \mathrm{G}^{\theta}$, within the range of $-20-0 \mathrm{~kJ} / \mathrm{mol}$, indicated that the mechanism of the adsorption process was mainly physical adsorption. The $\Delta S^{\theta}$ was positive, reflecting the randomness at the solid-liquid interface, during the increasing MB-NPC adsorption.

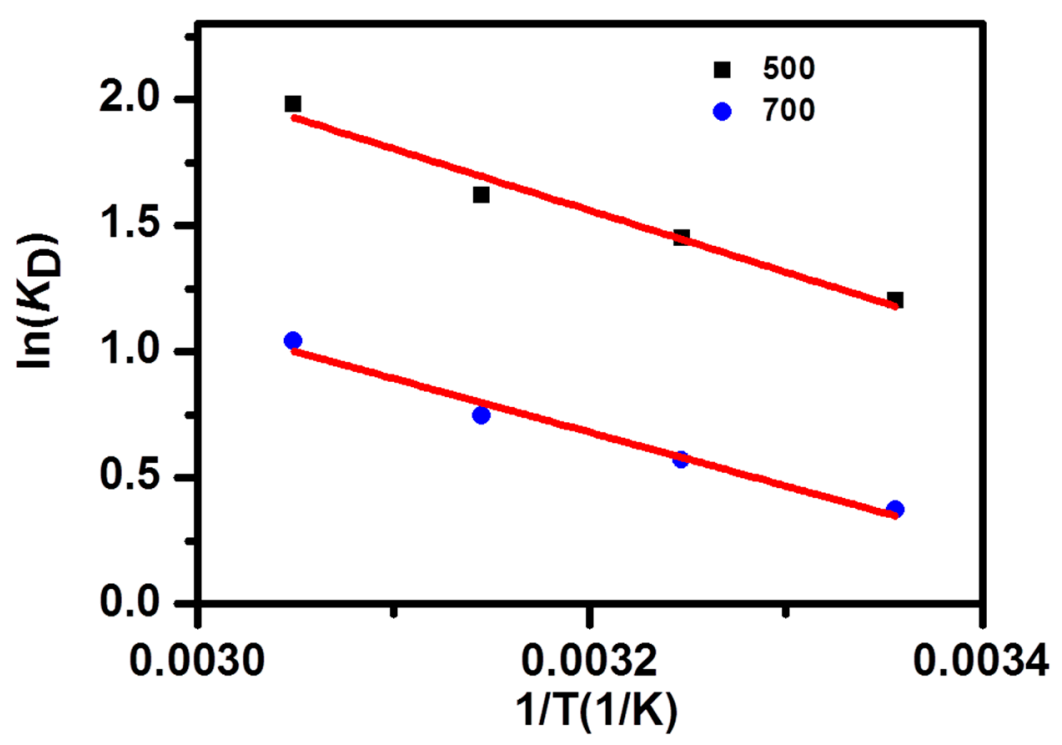

Figure 7. The plot of $\ln K_{\mathrm{D}}$ versus $1 / \mathrm{T}$ for the adsorption of MB on the NPC samples.

Table 3. Thermodynamic parameters for the adsorption of MB on the NPC samples.

\begin{tabular}{|c|c|c|c|c|c|c|}
\hline$C_{0}(\mathrm{mg} / \mathrm{L})$ & $\mathbf{T}(\mathrm{K})$ & $q_{\mathrm{e}}(\mathrm{mg} / \mathrm{g})$ & $K_{\mathrm{D}}$ & $\Delta \mathrm{G}^{\theta}(\mathrm{kJ} / \mathrm{mol})$ & $\Delta \mathrm{H}^{\Theta}(\mathrm{kJ} / \mathrm{mol})$ & $\Delta S^{\theta}(\mathrm{kJ} / \mathrm{mol} / \mathrm{K})$ \\
\hline \multirow{4}{*}{500} & 298 & 385 & 3.32 & -2.98 & \multirow{4}{*}{20.28} & \multirow{4}{*}{0.078} \\
\hline & 308 & 405 & 4.26 & -3.71 & & \\
\hline & 318 & 417 & 5.05 & -4.28 & & \\
\hline & 328 & 439 & 7.24 & -5.40 & & \\
\hline \multirow{4}{*}{700} & 298 & 414 & 1.45 & -0.92 & \multirow{4}{*}{17.69} & \multirow{4}{*}{0.062} \\
\hline & 308 & 447 & 1.79 & -1.46 & & \\
\hline & 318 & 475 & 2.11 & -1.98 & & \\
\hline & 328 & 517 & 2.83 & -2.84 & & \\
\hline
\end{tabular}

Different $\mathrm{pH}$ values of the solution were considered to be another factor in the MB-NPC adsorption. As the $\mathrm{pH}$ values of the wasted water were various in practice, it was necessary to evaluate the effect of the $\mathrm{pH}$ values on the dye removal technologies. The $\mathrm{pH}$ values could affect the adsorption capacity because they could remarkably change the surface charge of the adsorbent. They could also influence the electrostatic interactions and chemical reaction between adsorbates and the adsorbent on active sites [56]. In this study, the $\mathrm{pH}$ values were changed from 4 to 10 (Figure 8). The adsorption capacity showed a negligible change within the entire $\mathrm{pH}$ region, indicating that the adsorption capacity of the NPC with MB, was not influenced by this factor. 


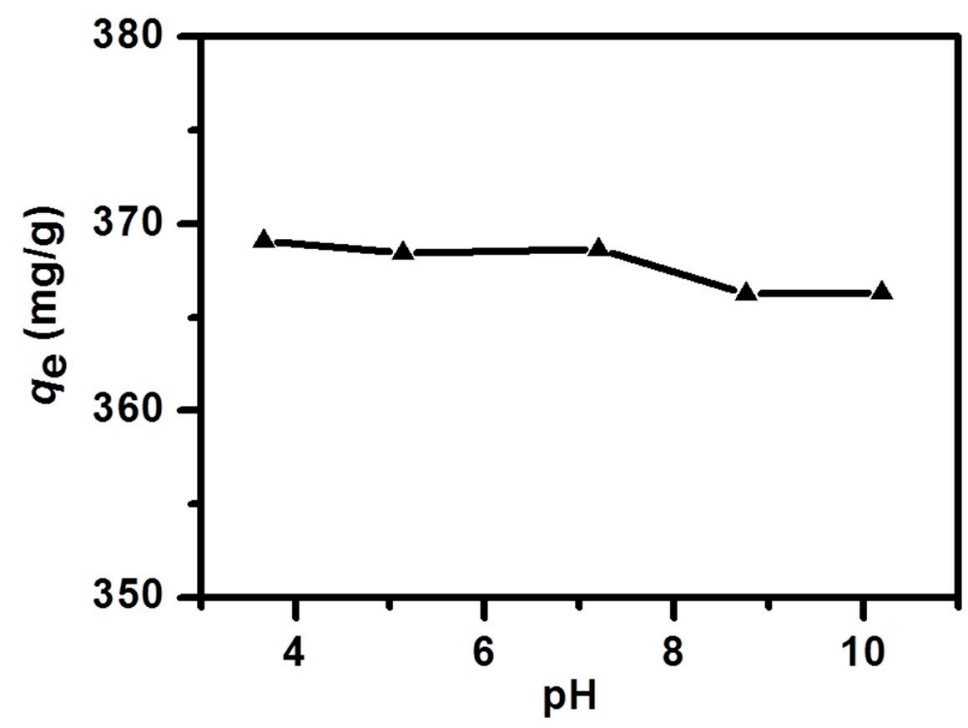

Figure 8. Influence of the solution's initial $\mathrm{pH}$ on the MB adsorption onto the NPC.

The electrochemical properties were studied in a full-cell setup, to evaluate the capacitive performance of $\mathrm{NPC}$, in practice. Using $1 \mathrm{MLi}_{2} \mathrm{SO}_{4}$ aqueous solution as the electrolyte, $\mathrm{CV}$ measurement could be tested in a wide voltage window from $0-1.2 \mathrm{~V}$, at different scanning rates (Figure $9 \mathrm{a}$ ). The similar shape for all curves suggested a negligible diffusion limitation in higher scanning rates. The CV curves showed a little distortion from rectangular, especially at a high scan rate, which might be due to the porosity saturation [57] and the poor mobility of highly solvated ion $\mathrm{Li}^{+}$and highly solvated anion $\mathrm{SO}_{4}{ }^{2-}$ [58]. The specific capacitance derived from the $\mathrm{CV}$, at a scanning rate of $1 \mathrm{mV} / \mathrm{s}$, was calculated to be $226 \mathrm{~F} / \mathrm{g}$ (Figure 9c). The large specific capacitance was benefits of the interconnected structure of the NPC. The interconnected structure could provide a good electron transfer, leading to a good electrical conductivity. In addition, this interconnected structure, formed from the aggregation of the ultra-small crystal, could supply the connected pores for a continuous and efficient ion diffusion. GCD was conducted to evaluate the stability in the potential window from 0 and $1.2 \mathrm{~V}$, in a $1 \mathrm{M}$ $\mathrm{Li}_{2} \mathrm{SO}_{4}$ aqueous solution (Figure $9 \mathrm{~b}$ ). NPC exhibits almost symmetrical triangular shapes within the wide potential window, implying a reversible capacitive performance, contributed by the electric double layer supercapacitor (EDLC), and excellent coulombic efficiency. To better analyze the rate performance of the electrode materials, the GCD curves of NPC, at various current densities from 1 to $20 \mathrm{~A} / \mathrm{g}$, were collected. The specific capacitances are 205, 179, 155, 143, and $128 \mathrm{~F} / \mathrm{g}$, at current densities of 1, 2, 5, 10, and $20 \mathrm{~A} / \mathrm{g}$, respectively (Figure 9c). The maximum energy density of NPC was $10.25 \mathrm{Wh} / \mathrm{kg}$ in aqueous electrolyte, among the highest values published. The Nyquist plot of the NPC revealed that the electrical conductivity was acquired from EIS measurements. In Figure 9d, from the intersection in the $Z^{\prime}$ axis, the interface contact resistance was as low as $0.12 \Omega$. The low charge transfer resistance could be revealed from the small diameter of a semicircle, which benefited from the interconnected structure. The almost vertical curve in the low-frequency region indicated a fast ion diffusion and an ideal capacitive behavior. Good cycling stability was another important factor for capacitors. The electrochemical stability of the NPC was further evaluated at a current density of $10 \mathrm{~A} / \mathrm{g}$. Figure $\mathrm{S} 4$ shows that there was still a $97.8 \%$ retention of capacitance, for the NPC electrodes, after 5000 cycles, confirming a long lifetime. 

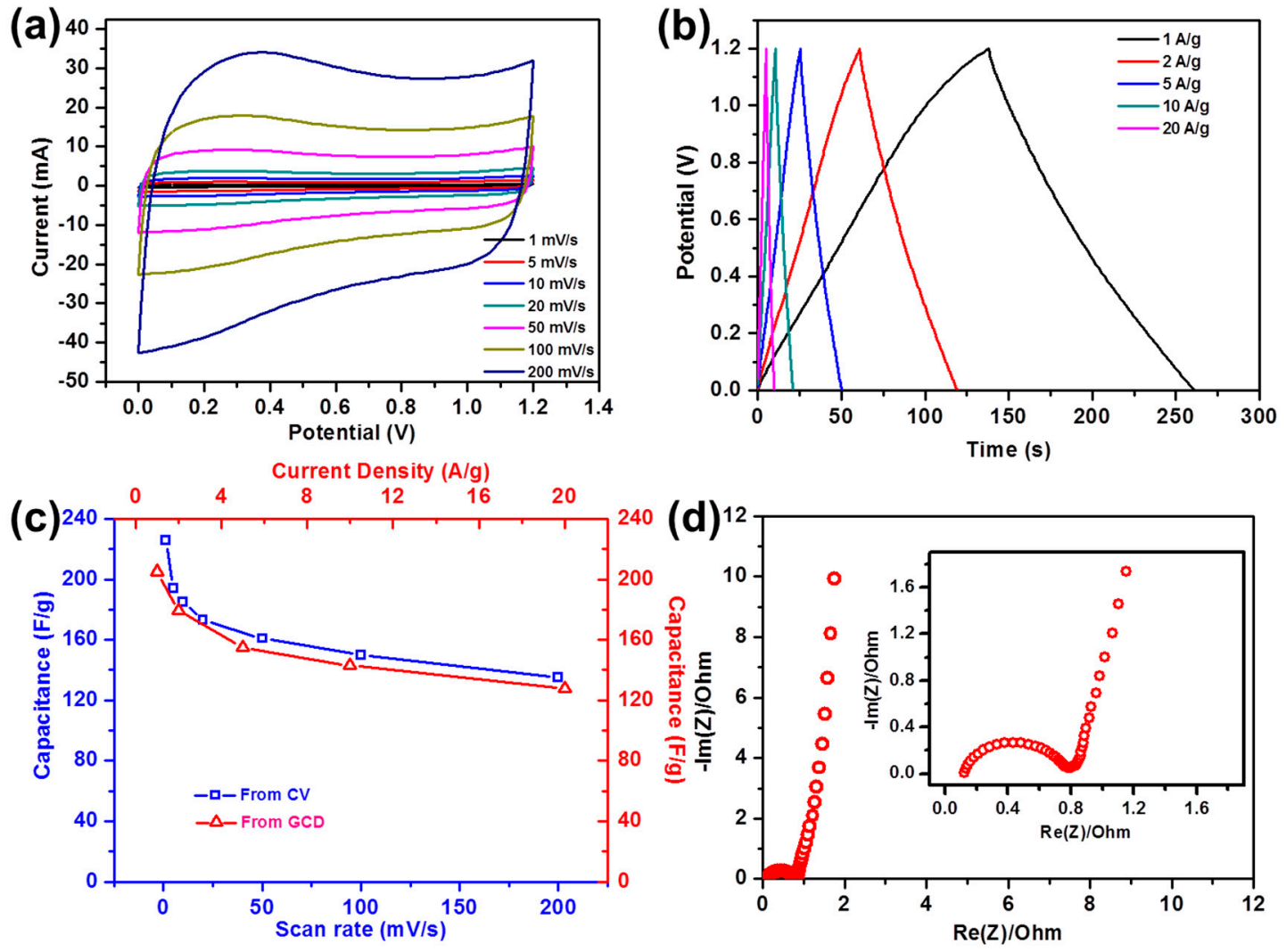

Figure 9. Cyclic voltammetry (CV) curves (a) and galvanostatic charging/discharging (GCD) curves (b) of NPC; Variations of the specific capacitances (c) of NPC from CV and GCD; Nyquist plots (d) of NPC (inset shows the Nyquist plots in a high-frequency region).

\section{Conclusions}

In summary, interconnected NPC was successfully prepared by direct carbonization of the ultra-small Al-MOC. With a porous structure, NPC had a high SSA $\left(1593 \mathrm{~m}^{2} / \mathrm{g}\right)$ and a large dye adsorption, with a maximum value of $415 \mathrm{mg} / \mathrm{g}$, proceeding the physical adsorption. The equilibrium adsorption isotherm and the adsorption kinetics have been fully discussed. The adsorption process was not influenced by the different $\mathrm{pH}$ values. Moreover, it was a spontaneous and endothermic process, proved by the thermodynamic studies. NPC, with an excellent adsorption capacity of MB, was believed to have excellent capacitive characteristics in supercapacitors, due to its large ion accessible area, good electrical conductivity, and suitable PSD. NPC exhibited a high specific capacitance of $226 \mathrm{~F} / \mathrm{g}$, in a symmetrical supercapacitor, suggesting a large potential in supercapacitors.

Supplementary Materials: The following are available online at http://www.mdpi.com/2079-4991/9/4/601/s1, Figure S1. X-ray diffraction (XRD) pattern of Al-based metal-organic complex (Al-MOC) and the peak position of simulated MIL-53 (Al); Figure S2. Scanning Electron Microscopy (SEM) image of nanoporous carbon (NPC); Figure S3. (a) Transmission electron microscopy (TEM) image of NPC with mesopores pointed by arrows at the edge, $(\mathbf{b}, \mathbf{c})$ High-resolution TEM images of the thin edges of NPC with mesopores pointed by arrows; Figure S4. Specific capacitance retention for NPC at a current density of $10 \mathrm{~A} / \mathrm{g}$ within 5000 cycles.

Author Contributions: Conceptualization, X.C.; Data curation, X.S. and S.Z.; Formal analysis, X.S.; Funding acquisition, X.C.; Supervision, E.M.; Writing—original draft, X.S.

Funding: This research was funded by the National Science Centre, Poland, within UMO-2017/25/B/ST8/02702.

Conflicts of Interest: The authors declare no conflict of interest. 


\section{References}

1. Han, S.; Sohn, K.; Hyeon, T. Fabrication of New Nanoporous Carbons through Silica Templates and Their Application to the Adsorption of Bulky Dyes. Chem. Mater. 2000, 12, 3337-3341. [CrossRef]

2. Zhang, S.; Shi, X.; Moszyński, D.; Tang, T.; Chu, P.K.; Chen, X.; Mijowska, E. Hierarchical Porous Carbon Materials from Nanosized Metal-organic Complex for High-Performance Symmetrical Supercapacitor. Electrochim. Acta 2018, 269, 580-589. [CrossRef]

3. He, C.; Hu, X.J. Anionic Dye Adsorption on Chemically Modified Ordered Mesoporous Carbons. Ind. Eng. Chem. Res. 2011, 50, 14070-14083. [CrossRef]

4. Blackburn, R.S. Natural polysaccharides and their interactions with dye molecules: Applications in effluent treatment. Environ. Sci. Technol. 2004, 38, 4905-4909. [CrossRef] [PubMed]

5. Ramakrishna, K.R.; Viraraghavan, T. Dye removal using low cost adsorbents. Water Sci. Technol. 1997, 36, 189-196. [CrossRef]

6. Cazetta, A.L.; Vargas, A.M.M.; Nogami, E.M.; Kunita, M.H.; Guilherme, M.R.; Martins, A.C.; Silva, T.L.; Moraes, J.C.G.; Almeida, V.C. NaOH-activated carbon of high surface area produced from coconut shell: Kinetics and equilibrium studies from the methylene blue adsorption. Chem. Eng. J. 2011, 174, 117-125. [CrossRef]

7. Bedin, K.C.; Martins, A.C.; Cazetta, A.L.; Pezoti, O.; Almeida, V.C. KOH-activated carbon prepared from sucrose spherical carbon: Adsorption equilibrium, kinetic and thermodynamic studies for Methylene Blue removal. Chem. Eng. J. 2016, 286, 476-484. [CrossRef]

8. Zhang, Y.J.; Xing, Z.J.; Duan, Z.K.; Li, M.; Wang, Y. Effects of steam activation on the pore structure and surface chemistry of activated carbon derived from bamboo waste. Appl. Surf. Sci. 2014, 315, 279-286. [CrossRef]

9. Hameed, B.H.; Din, A.T.M.; Ahmad, A.L. Adsorption of methylene blue onto bamboo-based activated carbon: Kinetics and equilibrium studies. J. Hazard. Mater. 2007, 141, 819-825. [CrossRef]

10. Tan, I.A.W.; Ahmad, A.L.; Hameed, B.H. Adsorption of basic dye on high-surface-area activated carbon prepared from coconut husk: Equilibrium, kinetic and thermodynamic studies. J. Hazard. Mater. 2008, 154, 337-346. [CrossRef] [PubMed]

11. Arami, M.; Limaee, N.Y.; Mahmoodi, N.M.; Tabrizi, N.S. Removal of dyes from colored textile wastewater by orange peel adsorbent: Equilibrium and kinetic studies. J. Colloid Interface Sci. 2005, 288, 371-376. [CrossRef]

12. Namasivayam, C.; Muniasamy, N.; Gayatri, K.; Rani, M.; Ranganathan, K. Removal of dyes from aqueous solutions by cellulosic waste orange peel. Bioresour. Technol. 1996, 57, 37-43. [CrossRef]

13. Kuo, C.Y.; Wu, C.H.; Wu, J.Y. Adsorption of direct dyes from aqueous solutions by carbon nanotubes: Determination of equilibrium, kinetics and thermodynamics parameters. J. Colloid Interface Sci. 2008, 327, 308-315. [CrossRef] [PubMed]

14. Yao, Y.J.; He, B.; Xu, F.F.; Chen, X.F. Equilibrium and kinetic studies of methyl orange adsorption on multiwalled carbon nanotubes. Chem. Eng. J. 2011, 170, 82-89. [CrossRef]

15. Kang, D.J.; Yu, X.L.; Ge, M.F.; Xiao, F.; Xu, H. Novel Al-doped carbon nanotubes with adsorption and coagulation promotion for organic pollutant removal. J. Environ. Sci. 2017, 54, 1-12. [CrossRef] [PubMed]

16. Kumar, R.; Ansari, M.O.; Barakat, M.A. Adsorption of Brilliant Green by Surfactant Doped Polyaniline/MWCNTs Composite: Evaluation of the Kinetic, Thermodynamic, and Isotherm. Ind. Eng. Chem. Res. 2014, 53, 7167-7175. [CrossRef]

17. Rathinam, K.; Singh, S.P.; Li, Y.L.; Kasher, R.; Tour, J.M.; Arnusch, C.J. Polyimide derived laser-induced graphene as adsorbent for cationic and anionic dyes. Carbon 2017, 124, 515-524. [CrossRef]

18. Ramesha, G.K.; Kumara, A.V.; Muralidhara, H.B.; Sampath, S. Graphene and graphene oxide as effective adsorbents toward anionic and cationic dyes. J. Colloid Interface Sci. 2011, 361, 270-277. [CrossRef]

19. Abdi, J.; Vossoughi, M.; Mahmoodi, N.M.; Alemzadeh, I. Synthesis of metal-organic framework hybrid nanocomposites based on GO and CNT with high adsorption capacity for dye removal. Chem. Eng. J. 2017, 326, 1145-1158. [CrossRef]

20. Zhu, J.Y.; Wang, Y.M.; Liu, J.D.; Zhang, Y.T. Facile One-Pot Synthesis of Novel Spherical Zeolite-Reduced Graphene Oxide Composites for Cationic Dye Adsorption. Ind. Eng. Chem. Res. 2014, 53, 13711-13717. [CrossRef] 
21. Qadri, S.; Ganoe, A.; Haik, Y. Removal and recovery of acridine orange from solutions by use of magnetic nanoparticles. J. Hazard. Mater. 2009, 169, 318-323. [CrossRef]

22. Asfaram, A.; Ghaedi, M.; Hajati, S.; Goudarzi, A.; Dil, E.A. Screening and optimization of highly effective ultrasound-assisted simultaneous adsorption of cationic dyes onto Mn-doped $\mathrm{Fe}_{3} \mathrm{O}_{4}$-nanoparticle-loaded activated carbon. Ultrason. Sonochem. 2017, 34, 1-12. [CrossRef] [PubMed]

23. El-Kady, M.F.; Strong, V.; Dubin, S.; Kaner, R.B. Laser Scribing of High-Performance and Flexible Graphene-Based Electrochemical Capacitors. Science 2012, 335, 1326-1330. [CrossRef] [PubMed]

24. Xu, Y.X.; Lin, Z.Y.; Zhong, X.; Huang, X.Q.; Weiss, N.O.; Huang, Y.; Duan, X.F. Holey graphene frameworks for highly efficient capacitive energy storage. Nat. Commun. 2014, 5, 4554. [CrossRef] [PubMed]

25. Winter, M.; Brodd, R.J. What are batteries, fuel cells, and supercapacitors? Chem. Rev. 2004, 104, 4245-4269. [CrossRef] [PubMed]

26. Balducci, A.; Dugas, R.; Taberna, P.L.; Simon, P.; Plee, D.; Mastragostino, M.; Passerini, S. High temperature carbon-carbon supercapacitor using ionic liquid as electrolyte. J. Power Sources 2007, 165, 922-927. [CrossRef]

27. Zhang, L.L.; Zhao, X.; Stoller, M.D.; Zhu, Y.W.; Ji, H.X.; Murali, S.; Wu, Y.P.; Perales, S.; Clevenger, B.; Ruoff, R.S. Highly Conductive and Porous Activated Reduced Graphene Oxide Films for High-Power Supercapacitors. Nano Lett. 2012, 12, 1806-1812. [CrossRef] [PubMed]

28. Chen, X.Y.; Chen, C.; Zhang, Z.J.; Xie, D.H.; Deng, X. Nitrogen-Doped Porous Carbon Prepared from Urea Formaldehyde Resins by Template Carbonization Method for Supercapacitors. Ind. Eng. Chem. Res. 2013, 52, 10181-10188. [CrossRef]

29. Zhang, Z.J.; Cui, P.; Chen, X.Y. Structure and Capacitive Performance of Porous Carbons Derived from Terephthalic Acid-Zinc Complex via a Template Carbonization Process. Ind. Eng. Chem. Res. 2013, 52, 16211-16219. [CrossRef]

30. Vinu, A.; Ariga, K.; Mori, T.; Nakanishi, T.; Hishita, S.; Golberg, D.; Bando, Y. Preparation and characterization of well-ordered hexagonal mesoporous carbon nitride. Adv. Mater. 2005, 17, 1648-1652. [CrossRef]

31. Ania, C.O.; Khomenko, V.; Raymundo-Pinero, E.; Parra, J.B.; Beguin, F. The large electrochemical capacitance of microporous doped carbon obtained by using a zeolite template. Adv. Funct. Mater. 2007, 17, 1828-1836. [CrossRef]

32. Lee, J.; Kim, J.; Hyeon, T. Recent progress in the synthesis of porous carbon materials. Adv. Mater. 2006, 18, 2073-2094. [CrossRef]

33. Xiao, J.-D.; Qiu, L.-G.; Jiang, X.; Zhu, Y.-J.; Ye, S.; Jiang, X. Magnetic porous carbons with high adsorption capacity synthesized by a microwave-enhanced high temperature ionothermal method from a Fe-based metal-organic framework. Carbon 2013, 59, 372-382. [CrossRef]

34. Torad, N.L.; Hu, M.; Ishihara, S.; Sukegawa, H.; Belik, A.A.; Imura, M.; Ariga, K.; Sakka, Y.; Yamauchi, Y. Direct Synthesis of MOF-Derived Nanoporous Carbon with Magnetic Co Nanoparticles toward Efficient Water Treatment. Small 2014, 10, 2096-2107. [CrossRef] [PubMed]

35. Jiao, C.; Wang, Y.; Li, M.; Wu, Q.; Wang, C.; Wang, Z. Synthesis of magnetic nanoporous carbon from metal-organic framework for the fast removal of organic dye from aqueous solution. J. Magn. Magn. Mater. 2016, 407, 24-30. [CrossRef]

36. Yang, S.J.; Kim, T.; Im, J.H.; Kim, Y.S.; Lee, K.; Jung, H.; Park, C.R. MOF-Derived Hierarchically Porous Carbon with Exceptional Porosity and Hydrogen Storage Capacity. Chem. Mater. 2012, 24, 464-470. [CrossRef]

37. Li, C.X.; Hu, C.G.; Zhao, Y.; Song, L.; Zhang, J.; Huang, R.D.; Qu, L.T. Decoration of graphene network with metal-organic frameworks for enhanced electrochemical capacitive behavior. Carbon 2014, 78, 231-242. [CrossRef]

38. Miao, L.; Zhu, D.Z.; Zhao, Y.H.; Liu, M.X.; Duan, H.; Xiong, W.; Zhu, Q.J.; Li, L.C.; Lv, Y.K.; Gan, L.H. Design of carbon materials with ultramicro-, supermicro- and mesopores using solvent- and self-template strategy for supercapacitors. Microporous Mesoporous Mater. 2017, 253, 1-9. [CrossRef]

39. Loiseau, T.; Serre, C.; Huguenard, C.; Fink, G.; Taulelle, F.; Henry, M.; Bataille, T.; Férey, G. A Rationale for the Large Breathing of the Porous Aluminum Terephthalate (MIL-53) Upon Hydration. Chem. Eur. J. 2004, 10, 1373-1382. [CrossRef]

40. Zhao, J.; Yang, L.; Li, F.; Yu, R.; Jin, C. Structural evolution in the graphitization process of activated carbon by high-pressure sintering. Carbon 2009, 47, 744-751. [CrossRef]

41. Dresselhaus, M.S.; Jorio, A.; Hofmann, M.; Dresselhaus, G.; Saito, R. Perspectives on Carbon Nanotubes and Graphene Raman Spectroscopy. Nano Lett. 2010, 10, 751-758. [CrossRef] 
42. Langmuir, I. The adsorption of gases on plane surfaces of glass, mica and platinum. J. Am. Chem. Soc. 1918, 40,1361-1403. [CrossRef]

43. Hall, K.R.; Eagleton, L.C.; Acrivos, A.; Vermeulen, T. Pore- and solid-diffusion kinetics in fixed-bed adsorption under constant-pattern conditions. Ind. Eng. Chem. Fundam. 1966, 5, 212-223. [CrossRef]

44. Freundlich, H. Über die Adsorption in Lösungen. Z. Phys. Chem. 1907, 57, 385-470. [CrossRef]

45. Gupta, V.K.; Ali, I.; Saini, V.K. Adsorption studies on the removal of Vertigo Blue 49 and Orange DNA13 from aqueous solutions using carbon slurry developed from a waste material. J. Colloid Interface Sci. 2007, 315, 87-93. [CrossRef] [PubMed]

46. Namasivayam, C.; Jeyakumar, R.; Yamuna, R.T. Dye removal from wastewater by adsorption on 'waste' $\mathrm{Fe}(\mathrm{III}) / \mathrm{Cr}(\mathrm{III})$ hydroxide. Waste Manag. 1994, 14, 643-648. [CrossRef]

47. Lagergren, S. Zur theorie der sogenannten adsorption gelöster stoffe. Kungliga Svenska Vetenskapsakademiens $1898,24,1-39$.

48. Ho, Y.S.; McKay, G. Pseudo-second order model for sorption processes. Process Biochem. 1999, 34, 451-465. [CrossRef]

49. Aksakal, O.; Ucun, H. Equilibrium, kinetic and thermodynamic studies of the biosorption of textile dye (Reactive Red 195) onto Pinus sylvestris L. J. Hazard. Mater. 2010, 181, 666-672. [CrossRef]

50. Vargas, A.M.M.; Cazetta, A.L.; Martins, A.C.; Moraes, J.C.G.; Garcia, E.E.; Gauze, G.F.; Costa, W.F.; Almeida, V.C. Kinetic and equilibrium studies: Adsorption of food dyes Acid Yellow 6, Acid Yellow 23, and Acid Red 18 on activated carbon from flamboyant pods. Chem. Eng. J. 2012, 181-182, 243-250. [CrossRef]

51. Khan, T.A.; Chaudhry, S.A.; Ali, I. Equilibrium uptake, isotherm and kinetic studies of Cd(II) adsorption onto iron oxide activated red mud from aqueous solution. J. Mol. Liq. 2015, 202, 165-175. [CrossRef]

52. Nethaji, S.; Sivasamy, A. Adsorptive removal of an acid dye by lignocellulosic waste biomass activated carbon: Equilibrium and kinetic studies. Chemosphere 2011, 82, 1367-1372. [CrossRef] [PubMed]

53. Cheung, W.H.; Szeto, Y.S.; McKay, G. Intraparticle diffusion processes during acid dye adsorption onto chitosan. Bioresour. Technol. 2007, 98, 2897-2904. [CrossRef] [PubMed]

54. Weber, W.J.; Morris, J.C. Kinetics of Adsorption on Carbon from Solution. J. Sanit. Eng. Div. 1963, 89, 31-60.

55. Fan, J.; Zhang, J.; Zhang, C.; Ren, L.; Shi, Q. Adsorption of 2,4,6-trichlorophenol from aqueous solution onto activated carbon derived from loosestrife. Desalination 2011, 267, 139-146. [CrossRef]

56. Zhang, C.; Ye, F.; Shen, S.; Xiong, Y.; Su, L.; Zhao, S. From metal-organic frameworks to magnetic nanostructured porous carbon composites: Towards highly efficient dye removal and degradation. RSC Adv. 2015, 5, 8228-8235. [CrossRef]

57. Vaquero, S.; Díaz, R.; Anderson, M.; Palma, J.; Marcilla, R. Insights into the influence of pore size distribution and surface functionalities in the behaviour of carbon supercapacitors. Electrochim. Acta 2012, 86, 241-247. [CrossRef]

58. Fic, K.; Lota, G.; Meller, M.; Frackowiak, E. Novel insight into neutral medium as electrolyte for high-voltage supercapacitors. Energy Environ. Sci. 2012, 5, 5842-5850. [CrossRef]

(C) 2019 by the authors. Licensee MDPI, Basel, Switzerland. This article is an open access article distributed under the terms and conditions of the Creative Commons Attribution (CC BY) license (http://creativecommons.org/licenses/by/4.0/). 